Jurnal Satyagraha

Vol.04, No.01, Pebruari 2021 - Agustus 2021

ISSN : 2620-6358

http://ejournal.universitasmahendradatta.ac.id/index.php/satyagraha

\title{
STRATEGI OPTIMALISASI MANAJEMEN PELAYANAN PUBLIK DI \\ TERMINAL MENGWI KABUPATEN BADUNG \\ (Studi kasus: Peralihan Terminal Ubung ke Terminal Mengwi)
}

\author{
Putu Eka Purnamaningsih dan Kadek Wiwin Dwi Wismayanti \\ Program Studi Administrasi Negara, FISIP, Univeritas Udayana \\ Bali, Indonesia \\ Email : wiwin.fisip@unud.ac.id; ekapurnama@unud.ac.id
}

\begin{abstract}
Abstrak
Terminal Mengwi merupakan jenis terminal tipe A yang mulai beroperasi pada tanggal 23 Oktober 2017. Kewenangan terminal yang memiliki luas 5 hektar ini sekarang dibawah Balai Pengelola Transportasi Darat (BPTD) XII Wilayah Provinsi Bali dan Provinsi Nusa Tenggara Barat. Adapun tujuan penelitian yang ingin dicapai adalah untuk memperoleh gambaran secara aktual mengenai kendala-kendala yang dihadapi dalam proses optimalisasi manajemen pelayanan publik di Terminal Mengwi. Penelitian ini menggunakan metode kualitatif deskriptif dengan teknik pengumpulan data berupa wawancara, observasi, dan dokumentasi Hasil penelitian ini menunjukkan bahwa optimalisasi manajemen pelayanan publik di Terminal Mengwi terlaksana, namun belum berjalan secara optimal. Upaya yang dilakukan terkait pengoptimalan yakni sudah dilakukan kegiatan sosialisasi kepada masyarakat dan para pengusaha otobus (PO) serta sudah disediakan 8 unit bus Trans Sarbagita dan proses perbaikan sarana dan prasarana di Terminal Mengwi.
\end{abstract}

Kata Kunci: Kebijakan Transportasi, Optimalisasi, Manajemen Pelayanan Publik, Terminal

\begin{abstract}
Mengwi Terminal is a type A type of terminal which began operations on October 23, 2017. The terminal has an area of 5 hectares now under the Land Transportation Management Center (BPTD) XII of Bali and West Nusa Tenggara Provinces. The research objective to be achieved is to obtain an actual picture of the constraints faced in the process of optimizing public service management in the Mengwi Terminal. This research uses descriptive qualitative method with data collection techniques in the form of interviews, observation, and documentation. The results of this study indicate that the optimization of public service management in the Mengwi Terminal is carried out, but not yet running optimally. Efforts made related to the optimization are already carried out socialization activities to the public and the autobus entrepreneurs (PO) as well as already provided 8 Trans Sarbagita bus units and the process of repairing facilities and infrastructure at the Mengwi Terminal.
\end{abstract}

Keywords: Transportation Policy, Optimization, Public Service Management, Terminal

Putu Eka Purnamaningsih 


\section{PENDAHULUAN}

Perkembangan wilayah yang terjadi di Provinsi Bali yang merupakan dampak dari pertambahan jumlah penduduk yang begitu cepat, mengakibatkan peningkatan di berbagai sektor kehidupan masyarakat yang salah satu diantaranya adalah sektor sosial ekonomi. Peningkatan yang terjadi pada sektor sosial ekonomi di Bali mengakibatkan meningkatnya kegiatan transportasi sehingga membawa konsekuensi kebutuhan terhadap sarana dan prasarana transportasi. Salah satu pembangunan terminal angkutan jalan yang harus bisa mendukung sistem transportasi yang ada di provinsi.

Manajemen pelayanan pada sektor publik adalah keseluruhan kegiatan pengelolaan pelayanan yang dilakukan oleh pemerintah secara operasional dilaksanakan oleh instansi-instansi pemerintah atau badan hukum lain milik pemerintah sesuai dengan kewenangan, baik pelayanan yang sifatnya langsung diberikan kepada masyarakat maupun tidak langsung diberikan malalui kebijakan- kebijakan tertentu (Mindarti, 2013). Proses ini merupakan salah satu cara untuk mendorong terwujudnya pelayanan aparatur pemerintah. Kewajiban pemerintah yakni untuk memberikan pelayanan publik yang menjadi hak setiap warga negara. Bentuk pelayanan publik yang diberikan kepada masyarakat berdasarkan UndangUndang Republik Indonesia Nomor 25 tahun 2009 tentang Pelayanan Publik, terkait ruang lingkup pelayanan meliputi pelayanan barang publik dan pelayanan jasa publik serta pelayanan administratif (Pasal 5 UU Nomor 25 Tahun 2009).

Ruang lingkup pelayanan yang terkait pada penelitian ini yakni mengenai pelayanan jasa publik yang didalamnya termasuk pelayanan jasa transportasi. Pelayanan transportasi dalam peranannya sebagai penunjang dan penggerak serta pemerataan hasil-hasil pembangunan mutlak harus direncanakan, diatur, dan dikendalikan sedemikian rupa agar dapat berfungsi optimal. Kebijakan di bidang transportasi publik khususnya darat, berdasarkan Undang-Undang Republik Indonesia Nomor 22 tahun 2009 tentang Lalu Lintas dan Angkutan Jalan, sebagai bagian dari sistem transportasi untuk mendukung pembangunan ekonomi dan pengembangan wilayah. Sistem transportasi darat yang ada di Provinsi Bali adalah angkutan umum seperti Angkot (kopas) dan Metromini. Kemudian jaringan transportasi bus yang meliputi bus kota Trans Sarbagita, bus Antar Kota Dalam Provinsi (AKDP), dan bus Antar Kota Antar Provinsi (AKAP). Pusat dari jaringan sistem transportasi bus umum ini adalah Terminal Mengwi yang menjadi objek kajian dalam pemenuhan fungsi pelayanan publik.

Terminal Mengwi adalah terminal utama (terminal induk) satu-satunya yang ada di Provinsi Bali berfungsi sebagai "terminal sentral" dalam melayani pergerakkan penumpang keluar masuk pulau Bali maupun perjalanan internal di Bali. Terminal sentral ini nantinya diharapkan menjadi titik perpindahan (transfer point) arus penumpang dan kendaraan umum di Provinsi Bali dari wilayah Bali Barat menuju Bali Timur, Bali Selatan menuju Bali Utara atau sebaliknya (Arsip laporan operasional Terminal Mengwi, Kabupaten Badung 2016). Terminal Mengwi merupakan jenis terminal tipe A yang mulai beroperasi pada tanggal 23 Oktober 2017. Berdasarkan pasal 35 ayat (1) Peraturan Menteri Perhubungan Republik Indonesia Nomor 132 Tahun 2015 tentang Penyelenggara Penumpang Angkutan Jalan, pengoperasian terminal penumpang tipe A diselenggarakan oleh Pemerintah Pusat melalui Kementerian Perhubungan Direktur Jendral Perhubungan Darat resmi mengelola Terminal Mengwi sebagai terminal pusat di Bali. Kewenangan terminal yang memiliki luas 5 hektar ini sekarang dibawah Balai Pengelola Transportasi Darat (BPTD) XII Wilayah Provinsi Bali dan Provinsi Nusa Tenggara Barat dan diperkuat dengan terbitnya kartu pengawas (KP) untuk bus 
http://ejournal.universitasmahendradatta.ac.id/index.php/satyagraha

Antar Kota Antar Provinsi (AKAP). Sejak awal beroperasi jumlah bus Antar Kota Antar Provinsi (AKAP) yang masuk di Terminal Mengwi berdasarkan data Balai Pengelola Transportasi Darat, sejauh ini belum berjalan secara optimal.

Pada penelitian ini akan difokuskan pada manajemen pelayanan publik terkait dengan standar pelayanan publik yang belum berjalan secara optimal di Terminal Mengwi, Kabupaten Badung, Provinsi Bali. Dari urian tersebut, maka rumusan masalah yang hendak di jawab pada penelitian ini, yaitu bagaimana optimalisasi manajemen pelayanan publik di Terminal Mengwi, Kabupaten Badung, Provinsi Bali?

\section{METODE PENELITIAN}

Metode penelitian yang digunakan dalam penelitian ini adalah penelitian kualitatif Singarimbun dan Efendi:1989:4 menyatakan dimana bahwa penelitian kualitatif merupakan penelitian dengan pendekatan deskriptif, penelitian deskriptif yang dimaksudkan sebagai pengukuran fenomena sosial tertentu yang mampu mengembangkan konsep serta menghimpun fakta tetapi tidak melakukan hipotesis, sebagaimana hasil wawancara akan digunakan serta dijabarkan sehingga menghasilkan analisis deskriptif sebagaimana dalam penelitian kualitatif.Teknik pengumpulan data dalam Penelitian ini dilakukan dengan mengumpulkan data primer dan data sekunder. Pengumpulan data yang dilakukan dalam penelitian ini menggunakan teknikteknik pengumpulan data sebagai berikut: Observasi langsung ke lokasi penelitian pada Terminal Mengwi Kabupaten Badung dalam rangka penelusuran data yang tidak diperoleh dalam wawancara, maupun datadata sekunder. Wawancara mendalam (indepth interview) yang dilakukan terhadap narasumber untuk mengetahui secara persis fenomena-fenomena tentang optimalisasi pelayanan terminal yang ingin diketahui. Data yang akan diperoleh langsung dari informan menjadi sumber data dalam penelitian ini adalah para aktor dalam proses optimalisasi pelayanan publik di terminal mengwi.

\section{HASIL DAN PEMBAHASAN}

Gambaran Umum Terminal Mengwi Terminal Mengwi adalah terminal utama (terminal induk) penumpang tipe A satu-satunya yang ada di Provinsi Bali. Terminal Mengwi berlokasi di Jalan Mengwi-Mengwitani, Kecamatan Mengwi, Kabupaten Badung, Provinsi Bali. Awalnya, Terminal Mengwi merupakan area persawahan yang luas lalu dibangun menjadi Terminal Penumpang Tipe A Mengwi dengan luas secara keseluruhan 5 hektar. Terminal Penumpang Tipe A Mengwi berfungsi melayani penumpang umum untuk angkutan antar kota antar provinsi (AKAP), angkutan antar kota dalam provinsi (AKDP), angkutan kota (Angkot), dan angkutan pedesaan (Angdes). Adapun hal yang menyebabkan dibangunnya Terminal Tipe A Mengwi adalah kebutuhan Provinsi Bali akan Terminal Tipe A yang representatif mampu berfungsi sebagai "terminal sentral" dalam melayani pergerakkan penumpang keluar masuk pulau Bali maupun perjalanan internal di Bali.

\section{Hasil Temuan Peneliti}

Prosedur Pelayanan

Pelayanan pengoperasian di Terminal Mengwi sudah terlaksana, namun pelaksanaan tersebut masih belum dapat berjalan secara optimal. Adapun faktor yang mempengaruhi belum optimmalnya pelayanan di Terminal yakni kurangnya Sumber Daya Manusia (SDM), seperti petugas pengaturan lalu lintas, petugas kesehatan, petugas Penyidik Pegawai Negeri Sipil (PPNS), dan petugas penguji kendaraan bermotor.

Waktu Pelayanan

Waktu yang diperlukan untuk mekanisme keberangkatan penumpnag sesuai dengan jadwal dan tujuan keberangkatan yang telah 
ditetapkan dari pihak masing-masing bus. Bus akan datang setiap 30 menit untuk menurunkan penumpang masuk ke Terminal Mengwi. Angkutan antar kota dalam provinsi (AKDP) mulai beroperasi jam 06.00 Wita hingga dengan 21.00 Wita, sedangkan angkutan sewa umum tidak dijadwalkan waktu kedatangan dan keberangkatannya karena angkutan ini merupakan sebuah bus pariwisata yang datang ke Terminal Mengwi dan para penumpangnya yang ingin pergi ke wisata.

Biaya Pelayanan

Bus dan penumpang yang masuk ke Terminal Mengwi hanya dikenakan biaya uang parkir saja dan tidak dikenakan biaya tiket masuk. Hal ini dikarenakan Pemerintah Pusat melalui Kementerian Perhubungan Direktorat Jendral Perhubungan Darat belum membuat peraturan mengenai perda retribusi tersebut. Terminal Mengwi pun masih dalam tahap pembenahan insfrastruktur berupa sarana dan prasarana terminal, ketika pembenahan sudah maksimal secara keseluruhan maka akan ada biaya retribusi atau biaya pelayanan tersebut. Biaya pelayanan jasa angkutan di Terminal Mengwi yakni pertama Angkutan Kota Antar Provinsi (AKAP) dikenakan biaya sesuai dengan tujuan penumpang yang diinginkan.

Produk Layanan

Produk pelayanan atau jasa angkutan di Terminal Mengwi didasarkan pada Peraturan Menteri Perhubungan Republik Indonesia No. PM 132 Tahun 2015 tentang Penyelenggaraan Terminal Penumpang Angkutan Jalan, dalam pasal 8 dijelaskan tipe terminal. Terminal Penumpang Tipe A merupakan yang peran utamanya melayani penumpang umum untuk angkutan kota antar provinsi (AKAP), angkutan antar kota dalam provinsi (AKDP), angkutan kota (Angkot) serta angkutan pedesaan (Angdes). Untuk di Terminal Mengwi Tipe $\mathrm{A}^{+}$(pariwisata) berupa angkutan taksi dan angkutan sewa umum

\section{Sarana Prasarana}

Sarana dan prasarana yang ada di Terminal Mengwi belum sesuai dengan Peraturan Menteri Perhubungan No. 132 Tahun 2015 tentang Penyelenggaraan Terminal Penumpang Angkutan Jalan. Adapun sarana- prasarana dan fasilitas yang ada di Terminal Mengwi yakni fasilitas ruang tunggu keberangkatan, tempat parkir, tempat pembelian tiket, toilet, penerangan, televisi, komputer, terminal keberangkatan dan kedatangan bus AKAP, AKDP, Angkot, dan Angdes, terminal bus singgahan (pariwisata).

Kompetensi Petugas Pemberi Pelayanan Kompetensi maupun pendidikan sangat diperlukan oleh petugas serta pendidikan tersebut hendaknya sesuai dengan bidang pekerjaannya. Petugas yang bekerja di Terminal Mengwi memiliki jenjang pendidikan minimal SMA (khusus lulusan SMA akan mendapatkan diklat pelatihan teknis pelayanan di Balai Pengelola Transportasi Darat), D2 lulusan Balai Pelatihan Pendidikan Transportasi Darat (BPPTD), D3 ahli LLAC (Lalu Lintas Angkutan Jalan), dan rata-rata sudah S1. Petugas yang memiliki kompetensi akan lebih cepat, cekatan, disiplin, dan mahir dalam memberikan pelayanan, dari pada petugas pelayanan yang kurang berkompetensi. Namun, petugas masih terkendala bahasa asing ketika penumpang interlokal yang datang ke Terminal Mengwi.

\section{SIMPULAN}

Kesimpulan yang bisa ditarik dalam penelitian ini adalah pengoptimalan manajemen pelayanan publik di Terminal Mengwi, Kabupaten Badung, Provinsi Bali sejauh ini terlaksana, namun belum berjalan secara optimal serta belum sesuai dengan peraturan yang telah ditetapkan. Beberapa poin yang dapat diambil berdasarkan teori yang penulis gunakan menurut Ratminto dan Atik mengenai standar pelayanan publik yakni, sebagai 1) Prosedur Pelayanan berupa standar operasional prosedur (SOP) belum 
http://ejournal.universitasmahendradatta.ac.id/index.php/satyagraha

terlaksana secara optimal, sebab masih kurangnya petugas untuk di Terminal Mengwi. Waktu Pelayanan mengenai waktu keberangkatan yang tidak sesuai dengan jam keberangkatan yang ditentukan dari pihak masing-masing perusaha otobus (PO) bus antar kota antar provinsi (AKAP).Biaya Pelayanan atau tarif angkutan sudah sesuai dengan biaya angkutan yang telah ditetapkan, namun penumpang lebih memilih membeli lewat online dari pada membeli langsung di loket-loket yang sudah disediakan di Terminal Mengwi. Hal ini yang mengakibatkan pihak PO mengalami kerugian.

Produk Pelayanan yakni jenis pelayanan jasa angkutan yang disediakan sudah digunakan dengan baik oleh penumpang, namun di Terminal Mengwi masih belum optimalnya angkutan antar kota dalam provinsi (AKDP) serta belum tersedianya jalur transportasi lanjutan dan halte untuk kelengkapan trayek kendaraan umum dari dan ke Terminal Mengwi ataupun ke tempat lain di berbagai titik strategis untuk mempermudah akses transportasi publik. Sarana dan Prasarana berupa perlengkapan kerja, fasilitas, serta barang atau benda tidak bergerak yang dapat menunjang dan mendukung pelaksanaan tugas dan fungsi unit kerja di Terminal Mengwi untuk pelayanan angkutan antar kota antar provinsi (AKAP) masih dalam proses perbaikan dan renovasi serta pelayanan untuk AKDP, Angkot, Angdes, gedung kantor pengelola terminal, dan pembuatan pintu keluar terminal masih dalam proses perencanaan kedepan serta dilakukan perombakan jalur khusus drop off penjemputan penumpang dan perbaikan zona pelayanan terminal sesuai dengan Peraturan Menteri Perhubungan Republik Indonesia Nomor PM 132 tahun 2015 tentang Penyelenggaraan Terminal Penumpang Angkutan Jalan. Kompetensi Petugas Pemberi Pelayanan berdasarkan pengetahuan, keahlian, keterampilan, sikap, dan perilaku di Terminal Mengwi masih terkendala dalam penggunaan bahasa Asing.
Karena terdapat penumpang interlokal yang datang ke Terminal Mengwi serta supir bus AKAP yang kurang memberikan rasa aman saat mengemudi bus terhadap penumpang yang menggunakan jasa angkutan bus tersebut.

\section{DAFTAR PUSTAKA}

Atik Septi \& Ratminto. 2005. Manajemen Pelayanan, disertai dengan penerapan citizen's charter dan standar pelayanan minimal. Yogyakarta : Perpustakaan Pelajar.

Badrudin. 2015. Dasar-Dasar Manajemen. Bandung. Hayat. 2017. Manajemen

Pelayanan Publik. Jakarta.

Pasolong, Harbani. 2014. Teori Administrasi Publik. Bandung.

Satori, D., \& Komariah, A. 2014. Metodologi Penelitian Kualitatif. Bandung. Sinambela,

Thoha, Miftah. 2008. Ilmu Administrasi Publik Kontemporer. Jakarta. Wijaya, Tony. 2011. Manajemen Kualitas Jasa. PT. Indeks, Jakarta Barat

Laporan Kedatangan dan Keberangkatan Terminal Penumpang Tipe A Mengwi Kabupaten Badung 2012-2016.

Laporan Operasional Terminal Penumpang Tipe A Mengwi Kabupaten Badung 2016

Undang-Undang Republik Indonesia Nomor 22 Tahun 2009 Tentang Lalu Lintas Dan Angkutan Jalan 